\title{
MODEL NUMBERED HEADS TOGETHER DENGAN PERMAINAN NURIKABE UNTUK MENINGKATKAN HASIL BELAJAR
}

\author{
Oda Sulasry Adun ${ }^{1}$, Trija Fayeldi ${ }^{2}$, Yuniar Ika Putri Pranyata ${ }^{3}$ \\ Pendidikan Matematika. Universitas Kanuruhan Malang ${ }^{1,2,3}$ \\ Sulasryadun@gmail.com¹,Trija_fayeldi@unikama.ac.id ${ }^{2}$,Yuniar.mat@unikama.ac.id ${ }^{3}$
}

\begin{abstract}
Abstrak. Pembelajaran matematika di kelas X IPA masih menggunakan metode konvensional. Metode konvensional yaitu pelajaran berpusat pada guru tanpa memberikan kesempatan pada peserta didik untuk mengkonstruksi pengetahuan secara maksimal, masih kurangnya penggunaan permainan yang lebih menarik untuk mendukung metode mengajar. Tujuan penelitian ini adalah mendeskripsikan langkah-langkah penerapan model pembelajaran kooperatif numbered heads together dengan permainan nurikabe yang meningkatkan hasil belajar peserta didik kelas X IPA SMA Taman Madya Malang. Pendekatan yang digunakan adalah pendekatan kualitatif. Subjek penelitian ini adalah peserta didik kelas X IPA yang berjumlah 16. Instrumen penelitian berupa perangkat pembelajaran, lembar kerja peserta didik, lembar observasi guru, lembar observasi peserta didik, catatan lapangan dan soal tes. Hasil belajar diperoleh dari tes akhir setiap siklus. Hasil pembelajaran dengan model Numbered Heads Together dengan permainan Nurikabe menunjukkan peningkatan dari setiap siklus. Pada siklus I, persentase ketuntasan peserta didik sebesar $80 \%$. Pada siklus II, persentase ketuntasan peserta didik sebesar 86,67\%. Dengan demikian, peningkatan hasil belajar sebesar 6,67\%. Hasil observasi aktifitas guru pada siklus I sebesar $89,72 \%$ dan siklus II sebesar $97,08 \%$. Sedangkan aktifitas peserta didik siklus sebesar $88,8 \%$ dan pada siklus II sebesar 96,38\%. Disimpulkan bahwa langkah model pembelajaran Numbered Heads Together dengan permainan Nurikabe dapat meningkat hasil belajar.
\end{abstract}

Kata Kunci: Numbered Heads Together , Nurikabe; hasil belajar.

\section{PENDAHULUAN}

Pembelajaran merupakan proses interaksi antara siswa dan guru dengan menggunakan sumber belajar dan lingkungan belajar. Ambarini (2010) menyatakan bahwa proses pembelajaran pada dasarnya merupakan interaksi pendidik (guru) dengan peserta didik (siswa) untuk mencapai tujuan belajar yang diharapkan. Untuk itu, guru harus memiliki strategi dalam proses belajar mengajar, agar siswa dapat belajar secara efektif dan efisien.

Salah satu kemampuan matematis yang harus dimiliki siswa adalah kemampuan pemecahan masalah matematika. Kemampuan pemecahan masalah merupakan kecakapan atau potensi yang dimiliki siswa dalam menyelesaikan permasalahan dan mengaplikasikannya dalam kehidupan sehari-hari (Gunantara, Suarjana, \& Riastini, 2014). Melihat fenomena yang terjadi, maka dalam pembelajaran matematika diperlukan suatu metode mengajar dan penilaian yang bervariasi. Wahyuni, Rahayu, \& Widyati (2017) yang mengatakan bahwa pembelajaran matematika di sekolah menjadi kurang bermakna disebabkan oleh kemampuan berpikir kritis matematis yang kurang dikembangkan oleh siswa. Sehingga, kemampuan berpikir kritis matematis harus dimiliki bahkan dikembangkan oleh siswa sebagai upaya menjadikan pembelajaran matematika yang bermakna di sekolah. Dalam penggunaan, metode mengajar tidak harus sama untuk semua pokok bahasan, sebab dapat terjadi bahwa suatu metode mengajar tertentu cocok untuk satu pokok bahasan tetapi tidak untuk pokok bahasan yang lain.

Ada beberapa faktor yang menyebabkan peserta didik tidak menyukai pelajaran matematika. Pertama, cara mengajar guru yang masih menggunakan metode konvensional. Metode konvensional yaitu pelajaran berpusat pada guru tanpa memberikan kesempatan pada peserta didik untuk mengkonstruksi pengetahuan mereka secara maksimal. Kedua, masih kurangnya penggunaan permainan yang lebih menarik untuk mendukung metode mengajar. Hal inilah yang menyebabkan peserta didik cepat merasa bosan dan tidak tertarik untuk mengikuti pelajaran matematika. 
Berdasarkan hasil observasi dan wawancara yang telah dilakukan peneliti dengan guru mata pelajaran matematika di kelas X IPA SMA Taman Madya Malang pada tanggal 11 Oktober 2018, diperoleh informasi bahwa selama proses pembelajaran yang dilakukan di kelas X IPA SMA Taman Madya Malang, pada saat guru menjelaskan materi banyak siswa masih bermain sendiri di belakang atau mengobrol dengan teman sebangkunya sehingga, sebagian siswa belum memahami materi dalam pelajaran matematika sehingga hasil belajarnya rendah di kelas X IPA SMA Taman Madya Malang diperoleh data bahwa dari 16 peserta didik kelas X IPA, terdapat 10 peserta didik memperoleh nilai rata-rata 67,00 yang berarti tidak memenuhi standar Kriteria Ketuntasan Minimal (KKM) dan hanya 6 peserta didik yang memenuhi standar Kriteria Ketuntasan Minimal (KKM) yaitu 75. Salah satu model pembelajaran yang melibatkan peran peserta didik secara aktif adalah pembelajaran kooperatif. Slavin (dalam Sari dan Surya, 2017) mengatakan pembelajaran kooperatif adalah proses pembelajaran di mana siswa bekerja tugas bersama untuk saling membantu dalam satu kelompok. Dengan pemilihan model Numbered Heads Together (NHT), diharapkan pembelajaran yang terjadi dapat lebih bermakna dan memberi kesan yang kuat kepada peserta didik. Pembelajaran NHT merupakan tipe pembelajaran yang dirancang untuk mempengaruhi pola interaksi siswa dan memiliki tujuan untuk meningkatkan semangat semangat kerjasama dalam kelompok serta memberikan kesempatan kepada siswa untuk saling membagi ide-ide dan mendiskusikan jawaban yang paling tepat Lorina (2012:9). Upaya peneliti dalam meningkatkan hasil belajar peserta didik adalah dengan mengubah model pembelajaran yang tadinya menggunakan ceramah diganti dengan model pembelajaran kooperatif tipe numbered head together (NHT) dengan permainan Nurikabe. Permainan Nurikabe adalah suatu permainan yang berupa teka teki dimana teka teki tersebut jika peserta didik bisa memainkannya akan menambahkan level, diharapkan mampu meningkatkan daya tarik siswa untuk mengerjakan soal dan membuat kegiatan pembelajaran yang menyenangkan. Dengan demikian model numbered head together (NHT) dapat meningkatkan hasil belajar peserta didik dengan berbantuan permainan Nurikabe.

Berdasarkan penelitian sebelumnya dengan menerapkan strategi model numbered head together (NHT) yaitu pada penelitian Yansen (2014) diperoleh kesimpulan bahwa penerapan model pembelajaran kooperatif tipe NHT dapat meningkatkan hasil belajar siswa kelas VIIA SMPN 9 Palu dalam menyelesaikan pertidaksamaan linear satu variabel. Pada penelitian Sukmara (2011) menunjukkan bahwa model pembelajaran kooperatif tipe NHT yang digunakan pada pembelajaran pemecahan masalah luas bangun ruang sisi datar, dapat meningkatkan hasil belajar siswa kelas VIII D SMP Negeri 1 Sukarame.

Berdasarkan uraian di atas didapat kesimpulan bahwa penelitian yang dilakukan oleh Yansen (2013), dan Sukmara (2011), keduanya hanya mengunakan Tipe Numbered Heads Together (NHT). Adapun penelitian yang dilakukan pada artikel ini berbeda dengan penelitian mereka, penelitian yang laksanakan mengunakan permainan Nurikabe, Penggunaan permainan ini agar proses pembelajaran lebih menarik dan menyenangkan. Pembelajaran kooperatif tipe Numbered Heads Together (NHT) dapat dijadikan sebagai salah satu alternatif dalam meningkatkan hasil belajar matematika peserta didik.

Berdasarkan uraian di atas dapat disimpulkan bahwa pembelajaran numbered heads together (NHT) dengan permainan nurikabe merupakan pembelajaran yang dapat meningkatkan hasil belajar matematika siswa kelas X IPA SMA Taman Madya Malang.

\section{METODE PENELITIAN}

Penelitian ini dirancang dengan menggunakan penelitian tindakan kelas (PTK). Pendekatan yang digunakan dalam penelitian ini adalah pendekatan kualitatif. Penelitian ini mendeskripsikan proses pembelajaran dan hasil belajar, kemudian data disajikan secara deskriptif atau berupa kata-kata atau pernyataan-pernyataan yang diperoleh melalui pelaksana tindakan, memberi tes, menganalisis data, dan melaporkan hasil penelitian.

Penelitian ini dilaksanakan di SMA Taman Madya Malang, kabupaten Malang. Sumber data dalam penelitian ini adalah siswa kelas X IPA SMA Taman Madya Malang semester genap tahun ajaran 2018/2019 yang berjumlah 16 Peserta didik terdiri atas 8 laki-laki dan 8 perempuan dan observer yaitu teman sejawat dan guru pengajar matematika. 
Metode pengumpulan data yaitu (1) tes, (2) observasi, dan (3) catatan lapangan. Analisis data yang digunakan dalam penelitian adalah (1) mereduksi data, (2) penyajian data, dan (3) penarikan kesimpulan. Pengecekan keabsahan data dengan cara ketekunan pengamat, triangulasi dan pemeriksaan sejawat melalui diskusi. Strategi pembelajaran pembelajaran kooperatif Numbered Heads Together (NHT) dengan Permainan Nurikabe dalam satu tindakan menggunakan tahap-tahap yaitu tahap pra tindakan dan tahap pelaksanaan tindakan. Tahap inti yaitu (1) Pendahuluan, (2) Pembentukan kelompok, (3) Penyajian materi, (4) Aturan permainan Nurikabe, (5) Diskusi kelompok, (6) Pemberian Presentasi kelompok, (7) Evaluasi, serta (8) Memberikan penghargaan..

\section{HASIL DAN PEMBAHASAN}

\section{Pra Tindakan}

Pada pra tindakan diperoleh data Nilai ulangan peserta didik yang akan digunakan sebagai data awal untuk mengetahui kemampuan peserta didik. Nilai rata-rata seluruh peserta didik terlihat pada tabel 1:

Tabel 1. Hasil Ulangan Harian Peserta didik X IPA

\begin{tabular}{lc}
\hline \multicolumn{1}{c}{ Keterangan } & Hasil Ulangan Harian \\
\hline Jumlah Peserta didik yang tuntas & 7 \\
\hline $\begin{array}{l}\text { Jumlah Peserta didik yang belum } \\
\text { tuntas }\end{array}$ & 9 \\
\hline Rata-rata nilai kelas & 70,62 \\
\hline Persentase Peserta didik yang tuntas & $43,75 \%$ \\
\hline $\begin{array}{l}\text { Persentase Peserta didik yang tidak } \\
\text { tuntas }\end{array}$ & $56,25 \%$ \\
\hline
\end{tabular}

Dari tabel 1. terlihat bahwa nilai rata-rata kelas adalah 70,62. Kriteria ketuntasan minimal yang digunakan di sekolah yaitu 75. Siswa yang mendapat nilai 75 sebanyak 7 siswa dengan persentase ketuntasan $43,75 \%$, ketuntasan ini belum mencapai ketuntasan minimum yang ditentukan oleh sekolah dan yang ditetapkan oleh peneliti.

\section{Tindakan Siklus 1}

Tabel 2. Hasil Analisis Lembar Observasi Aktivitas Guru Siklus 1

\begin{tabular}{lcccc}
\hline \multirow{2}{*}{ Keterangan } & \multicolumn{4}{c}{ Siklus 1 } \\
\cline { 2 - 5 } & \multicolumn{2}{c}{ Pertemuan 1 } & \multicolumn{2}{c}{ Pertemuan 2 } \\
\cline { 2 - 5 } & $\mathbf{P 2}$ & $\mathbf{P 3}$ & $\mathbf{P 2}$ & $\mathbf{P 3}$ \\
\hline Perolehan skor & 63 & 64 & 36 & 37 \\
\hline Skor maksimal & 72 & 72 & 40 & 40 \\
\hline Persentase keberhasilan tindakan & $87,5 \%$ & $88,89 \%$ & $90 \%$ & $92,5 \%$ \\
\hline Rata-rata & \multicolumn{5}{c}{$89,72 \%$} \\
\hline Kategori & \multicolumn{5}{c}{ Baik } \\
\hline
\end{tabular}

Observasi kegiatan guru pada siklus 1 dilakukan oleh guru matematika SMA Taman Madya sebagai pengamat 1 dan 2 peneliti. Hasil analisis lembar observasi guru pada siklus 1 pertemuan pertama menunjukkan bahwa keberhasilan aktivitas guru sebesar 89,72\%. Hasil analisis lembar observasi guru dapat dilihat pada tabel 2 di atas. 
Tabel 3. Hasil Analisis Lembar Observasi Aktivitas Peserta Didik Siklus 1

\begin{tabular}{lcccc}
\hline \multirow{2}{*}{ Keterangan } & \multicolumn{4}{c}{ Siklus 1 } \\
\cline { 2 - 5 } & \multicolumn{2}{c}{ Pertemuan 1 } & Pertemuan 2 \\
\cline { 2 - 5 } & $\mathbf{P 3}$ & $\mathbf{P 4}$ & $\mathbf{P 3}$ & $\mathbf{P 4}$ \\
\hline Perolehan skor & 47 & 49 & 31 & 33 \\
\hline Skor maksimal & 56 & 56 & 36 & 36 \\
\hline Persentase keberhasilan tindakan & $83,92 \%$ & $87,5 \%$ & $86,11 \%$ & $91,67 \%$ \\
\hline Rata-rata & \multicolumn{5}{c}{$88,8 \%$} \\
\hline Kategori & \multicolumn{5}{c}{ Baik } \\
\hline
\end{tabular}

Observasi kegiatan peserta didik pada siklus 1 dilakukan oleh dua orang teman sejawat sebagai pengamat 3 dan pengamat 4 . Hasil analisis lembar observasi peserta didik pada siklus 1 menunjukkan bahwa keberhasilan aktivitas peserta didik sebesar $88,8 \%$. Hasil analisis lembar observasi peserta didik dapat dilihat pada tabel 3 di atas.

Tabel 4. Hasil Tes Peserta Didik Siklus 1

\begin{tabular}{lc}
\hline \multicolumn{1}{c}{ Keterangan } & Hasil Siklus 1 \\
\hline Jumlah peserta didik yang tuntas & 12 \\
\hline Jumlah peserta didik yang tidak tuntas & 3 \\
\hline Rata-rata nilai & 77,33 \\
\hline Persentase peserta didik yang tuntas & $80 \%$ \\
\hline Persentase peserta didik yang tidak tuntas & $20 \%$ \\
\hline
\end{tabular}

Hasil Belajar Peserta didik,Hasil analisis tes akhir siklus 1 menunjukkan bahwa peserta didik yang tuntas belajar sebanyak 12 peserta didik dari 15 peserta didik, sehingga persentase peserta didik yang tuntas belajar sebesar $80 \%$ dan persentase peserta didik yang tidak tuntas belajar sebesar $20 \%$ dengan nilai rata-rata kelas 77,33. Hasil analisis tes peserta didik pada siklus 1 dapat dilihat pada tabel 4 di atas.

Tabel 5. Hasil Catatan Lapangan Siklus 1

\begin{tabular}{|c|c|}
\hline Observasi & Keterangan \\
\hline 1. Aktivitas Peneliti & $\begin{array}{l}\text { a. Hanya sedikit peserta didik yang ramai. } \\
\text { b. Guru terlalu cepat dalam menjelaskan } \\
\text { materi. } \\
\text { c. Guru kurang dalam memberikan } \\
\text { penghargaan kepada peserta didik yang } \\
\text { aktif. }\end{array}$ \\
\hline 2. Aktivitas Peserta Didik & $\begin{array}{l}\text { a. Peserta didik kurang antusias untuk } \\
\text { menjawab, saat peneliti memberikan } \\
\text { pertanyaan. } \\
\text { b. Peserta didik mengganggu kosentrasi } \\
\text { teman yang menjelaskan hasil diskusi } \\
\text { mereka didepan kelas. } \\
\text { c. Peserta didi kurang memperhatikan saat } \\
\text { peneliti kurang menerangkan } \\
\text { d. Peserta didik jarang menulis rangkuman } \\
\text { hasil penjelasan }\end{array}$ \\
\hline
\end{tabular}


Hasil catatan lapangan menunjukkan bahwa masih banyak kekurangan pada siklus 1, baik dalam aktivitas guru maupun Peserta didik. Hasil catatan lapangan dapat dilihat pada Tabel 5 . di atas.

\section{Tindakan siklus II}

Tabel 6. Hasil Analisis Lembar Observasi Aktivitas Guru Siklus 2

\begin{tabular}{|c|c|c|c|c|}
\hline \multirow{3}{*}{ Keterangan } & \multicolumn{4}{|c|}{ Siklus 1} \\
\hline & \multicolumn{2}{|c|}{ Pertemuan 1} & \multicolumn{2}{|c|}{ Pertemuan 2} \\
\hline & $\mathbf{P 2}$ & P3 & $\mathbf{P 2}$ & P3 \\
\hline Perolehan skor & 70 & 71 & 38 & 39 \\
\hline Skor maksimal & 72 & 72 & 40 & 40 \\
\hline Persentase keberhasilan tindakan & $97,22 \%$ & $98,61 \%$ & $95 \%$ & $97,5 \%$ \\
\hline Rata-rata & \multicolumn{4}{|c|}{$97,08 \%$} \\
\hline Kategori & \multicolumn{4}{|c|}{ Sangat Baik } \\
\hline
\end{tabular}

Observasi kegiatan guru pada siklus 1 dilakukan oleh guru matematika SMA Taman Madya sebagai pengamat 1 dan pengamat 2 peneliti. Hasil analisis lembar observasi guru pada siklus 1 pertemuan pertama menunjukkan bahwa keberhasilan aktivitas guru sebesar 97,08\%. Hasil analisis lembar observasi guru dapat dilihat pada tabel 6 di atas.

Tabel 7. Hasil Analisis Lembar Observasi Aktivitas Peserta Didik Siklus 2

\begin{tabular}{|c|c|c|c|c|}
\hline \multirow{3}{*}{ Keterangan } & \multicolumn{4}{|c|}{ Siklus 1} \\
\hline & \multicolumn{2}{|c|}{ Pertemuan 1} & \multicolumn{2}{|c|}{ Pertemuan 2} \\
\hline & P3 & P4 & P3 & $\mathbf{P 4}$ \\
\hline Perolehan skor & 54 & 55 & 32 & 32 \\
\hline Skor maksimal & 56 & 56 & 32 & 32 \\
\hline Persentase keberhasilan tindakan & $96,42 \%$ & $92,21 \%$ & $96,89 \%$ & $100 \%$ \\
\hline Rata-rata & \multicolumn{4}{|c|}{$96,38 \%$} \\
\hline Kategori & \multicolumn{4}{|c|}{ Sangat Baik } \\
\hline
\end{tabular}

Observasi kegiatan peserta didik pada siklus 2 dilakukan oleh dua orang teman sejawat sebagai pengamat 3 dan pengamat 4 . Hasil analisis lembar observasi peserta didik pada siklus 2 menunjukkan bahwa persentase keberhasilan aktivitas peserta didik sebesar 96,38\%. Hasil analisis lembar observasi peserta didik dapat dilihat pada tabel 7 di atas.

Tabel 8. Hasil Tes Peserta Didik Siklus 2

\begin{tabular}{lc}
\hline \multicolumn{1}{c}{ Keterangan } & Hasil Siklus 2 \\
\hline Jumlah peserta didik yang tuntas & 13 \\
\hline Jumlah peserta didik yang tidak tuntas & 2 \\
\hline Rata-rata nilai & 85,33 \\
\hline Persentase peserta didik yang tuntas & $86,67 \%$ \\
\hline Persentase peserta didik yang tidak tuntas & $13,33 \%$ \\
\hline
\end{tabular}

Hasil analisis tes akhir siklus 2 menunjukkan bahwa peserta didik yang tuntas belajar sebanyak 13 peserta didik dari 15 peserta didik, sehingga persentase peserta didik yang tuntas belajar sebesar $86,67 \%$ dan persentase peserta didik yang tidak tuntas belajar sebesar 13,33\% dengan nilai rata-rata kelas 85,33 . Hasil analisis tes peserta didik pada siklus 2 dapat dilihat pada tabel 8 di atas. 
Tabel 9. Hasil Catatan Lapangan Siklus 2

\begin{tabular}{cll}
\hline \multicolumn{1}{c}{ Observasi } & \multicolumn{1}{c}{ Keterangan } \\
\hline 1. Aktivitas Peneliti. & $\begin{array}{l}\text { a. Guru sudah bisa menguasai kelas dengan } \\
\text { baik. } \\
\end{array}$ \\
& $\begin{array}{l}\text { b. Guru selalu memberikan motivasi } \\
\text { kepada peserta didik. }\end{array}$ \\
\hline 2. Aktivitas Peserta Didik. & $\begin{array}{l}\text { a. Peserta didik tampak lebih aktif dan } \\
\text { tidak ada satupun yang lesu dan tidur. }\end{array}$ \\
& b. Peserta didik aktif saat diskusi kelompok. \\
& c. Peserta didik percaya diri untuk maju \\
& mempresentasikan hasil diskusi \\
& kelompoknya.
\end{tabular}

Hasil catatan lapangan menunjukkan bahwa pada siklus 2, kekurangan pada siklus 1 sudah diperbaiki, baik dalam aktivitas guru maupun Peserta didik. Hasil catatan lapangan dapat dilihat pada tabel 9 di atas.

Pembelajaran kooperatif dengan menggunakan model Numbered Heads Together (NHT) dengan permainan Nurikabe pada materi peluang dalam penelitian ini meliputi beberapa tahapan, yaitu (1) Pendahuluan, (2) Pembentukan kelompok, (3) Penyajian materi, (4) Aturan Permainan (5) Diskusi kelompok, (6) Presentasi kelompok, (7) Evaluasi, dan (8) Memberikan penghargaan.

Pada tahap pendahuluan, guru menyampaikan salam, mengabsen peserta didik, dan menyampaikan tujuan pembelajaran. Penyampaian tujuan pembelajaran bertujuan untuk memberikan arahan tentang apa yang harus dikuasai dan dicapai peserta didik peda pembelajaran, serta memperlancarkan proses pembelajaran.

Pembentukan kelompok ini bertujuan agar peserta didik lebih mudah menemukan dan menguasai suatu konsep jika mereka saling mendiskusikan masalah tersebut dengan temannya. Anggota kelompok yang kurang mampu dapat bertanya kepada anggota kelompok yang lebih mampu mengenai hal-hal yang belum dipahami. Selanjutnya guru memberi nomor kepala kepada setiap peserta didik dalam kelompok. Masing-masing peserta didik diminta untuk memakai nomor yang sudah diberikan oleh guru. Kemudian guru menjelaskan tata cara pembelajaran kooperatif dengan menggunakan model Numbered Heads Together (NHT) dengan permainan Nurikabe. Setelah itu guru guru membagikan LKPD pada setiap kelompok dan mulai menjelaskan tugas dan tangungjawab setiap kelompok untuk menyelesaikan tugas berupa soal-soal yang ada pada LKPD dengan diskusi kelompok.

Kegiatan selanjutnya yaitu penyajian materi pada tahap ini, guru menjelaskan materi peluang, juga mengaitkan dengan pengalaman belajar siswa yang berkaitan dengan kehidupan sehari-hari. Guru juga memberikan contoh soal dan pembahasan untuk memperdalam pengetahuan peserta didik. Peserta didik yang tidak siap belajar tidak dapat mempelajari sesuatu secara efisien.

Aturan merupakan salah satu unsur penting yang menyatakan bahwa dalam suatu permainan harus terdapat pemain, adanya lingkungan untuk berinteraksi pemain, adanya aturan dan adanya tujuan yang ingin dicapai.

Dalam diskusi kelompok, setiap peserta didik bekerjasama untuk menggambarkan dan meyakinkan bahwa setiap orang mengetahui jawaban dari pertanyaan yang telah ada dalam LKPD. Diskusi merupakan tindak lanjut yang dapat memberi pengaruh positif yang besar terhadap sikap dan pengetahuan peserta didik. Pada tahap ini, guru berfungsi sebagai fasilitator. Guru membantu peserta didik untuk bekerja secara kooperatif dan membimbing kelompok yang mengalami kesulitan. Guru juga selalu memantau kegiatan kelompok dan memberi bimbingan jika diperlukan.

Berkaitan dengan presentasi kelompok, guru memanggil beberapa kelompok dengan nomor anggota yang disebutkan mengangkat tangan dan maju untuk mempresentasikan jawaban 
didepan kelas. Setelah semua soal dibahas, guru meminta siswa unruk kembali ke tempat duduk masing-masing untuk bersama-sama menarik kesimplan pmebeajaran yang sudah ditempuh.

Evaluasi pada tahap ini, guru memberikan kesimpulan dari hasil presentasi peserta didik dan memberikan jawaban akhir dari semua pertanyaan yang berhubungan dengan materi yang disajikan. Pelaksanaan pembelajaran dalam penelitian ini melputi siklus 1 dan siklus II. Untuk melakukan evaluasi, maka pada setiap akhir siklus diadakan tes. Tes ini digunakan untuk mengetahui sejauh mana peserta didik memahami materi yang dipelajari dan tes dikerjakan secara individu.

Pada akhir pembelajaran, peserta didik diminta untuk membuat kesimpulan berdasarkan hasil kerja kelompok. Dengan membuat kesimpulan berarti antara peserta didik telah berupaya untuk memahami dan menjelaskan apa yang diamatinya.

Penerapan pembelajaran kooperatif model NHT pada penelitian ini bertujuan untuk meningkatkan hasil belajar peserta didik pada materi peluang. Peningkatan hasil belajar peserta didik dapat dilihat dari perbandingan rata-rata nilai awal peserta didik sebelum tindakan dengan tindakan siklus 1 dan tindakan siklus II. Rata-rata nilai ulangan peserta didik, siklus 1 dan siklus II berturut-turut adalah 70,62, 77,33 dan 85,33. Nilai tersebut adalah rata-rata secara klasikal. Sedangkan persentase ketuntasan hasil belajar peserta didik berturut-turut adalah $43,75 \%, 80 \%$ dan $86,67 \%$.

Berdasarkan data respon Peserta didik terhadap pelajaran matematika dengan model pembelajaran kooperatif tipe NHT dengan permainan Nurikabe, Peserta didik merasa mudah memahami soal-soal khususnya pada materi peluang. Peserta didik menjadi lebih aktif dalam proses pembelajaran. Hal ini dibuktikan dengan antusias peserta didik dalam berdiskusi dengan teman-teman kelompoknya dalam menyelesaikan soal LKPD.

Kendala yang dihadapi pada saat melakukan penelitian mencakup beberapa hal, yaitu(a) Pada saat peneliti menyajikan materi beberapa peserta didik mengobrol sendiri di belakang dan tidak memperhatikan materi yang dijelaskan oleh guru, (b) Masih terdapat peserta didik yang belum mencapai KKM, (c) Masih terdapat peserta didik yang kurang aktif pada saat diskusi kelompok.

Untuk mengatasi kendala di atas solusi yang dilakukan oleh peneliti selama penelitian berlangsung: (a) Peneliti harus menegur langsung peserta didik yang ramai dan memantau tempat duduk peserta didik, (b) Memotivasi peserta didik dan memberi perhatian lebih kepada peserta didik yang belum mencapai KKM, (c) Kelompok akan membantu peserta didik dalam memahami materi.

\section{PENUTUP}

Dari hasil penelitian disimpulkan bahwa prosedur pembelajaran yang dikembangkan dalam penelitian ini berhasil sebagai suatu prosedur pembelajaran yang dapat membantu meningkatkan hasil belajar peserta didik di kelas. Pada tes akhir siklus 1, persentase ketuntasan peserta didik meningkat dari $43,75 \%$ menjadi $80 \%$ dan pada tes akhir siklus 2, persentase ketuntasan peserta didik menjadi $86,67 \%$. Berdasarkan hasil tersebut, hasil belajar peserta didik mengalami peningkatan sebesar 32,25\% pada siklus 1 dan 6,67\% pada siklus 2, Hasil observasi aktifitas guru pada siklus I sebesar $89,72 \%$ dan siklus II sebesar 97,08\%. Sedangkan aktifitas peserta didik siklus sebesar $88,8 \%$ dan pada siklus II sebesar 96,38\%. Berdasarkan hasil penelitian maka dapat disimpulkan langkah model pembelajaran Numbered Heads Together (NHT) dengan permainan Nurikabe dapat meningkat hasil belajar peserta didik kelas X IPA SMA Taman Madya Malang. Sehingga dapat disimpulkan bahwa model pembelajaran Numbered Heads Together (NHT) dengan permainan Nurikabe dapat meningkatkan hasil belajar peserta didik.

Beberapa saran yang perlu disampaikan sebagai berikut: a) Pada saat tanya jawab, sebaiknya guru menunjuk langsung peserta didik yang harus menjawab pertanyaan dari guru, sehingga tidak ada peserta didik yang mendominasi kegiatan tanya jawab pada saat proses belajar mengajar. b) Pada saat diskusi dan permainan, sebaiknya guru aktif memantau, membimbing, dan memotivasi agar aktivitas peserta didik berjalan sesuai dengan tujuan yang direncanakan. c) Bagi peneliti selanjutnya yang dijadikan referensi apabila menginginkan untuk mengadakan penelitian dengan model pembelajaran Numbered Heads Together diharapkan 
dapat melengkapi kekurangan yang ada, pada saat pembagian kelompok peserta didik bingung dengan kelompok yang sudah dibagikan karena peserta didik ramai.

\section{DAFTAR PUSTAKA}

Ambarini, N. 2010. Penerapan Pembelajaran Aktif Card Sort Disertai Mind Mapping Untuk Meningkatkan Minat Belajar Siswa Dalam Pembelajaran Biologi Siswa Kelas VIIE SMP Negeri 5 Surakarta. Jurnal Pembelajaran Biologi. Vol. 1 (1): 1-17.

Gunantara, G., Suarjana, M., \& Riastini, P. N. (2014). Penerapan Model Pembelajaran Problem Based Learning untuk Meningkatkan Kemampuan Pemecahan Masalah Matematika Siswa Kelas V. Jurnal Mimbar PGSD Universitas Pendidikan Ganesha, 2(1), 1-10. https://doi.org/10.1073/pnas.0703993104.

Lorina, Pirade. 2012. Penerapan Model Pembelajaran Kooperatif Tipe Numbered Head Together Berbantuan Media Gambar untuk Meningkatkan Hasil Belajar Siswa Pada Mata Pelajaran IPA Di Kelas IV SDN No. 1 Tanjung Padang: Palu. Universitas Tadulako. Elementary School of Education E-Journal, Media Publikasi Ilmiah Prodi PGSD Vol 2, Nomor 2.

Sari, M. and Surya, E. 2017. Improving The Learning Outcomes Of Students Using Numbered Heads Together Model In The Subjects Of Mathematics. International Journal of Sciences: Basic and Applied Research (IJSBAR), 33(3), pp. 311-319.

Sukmara, C. (2011). Pembelajaran Kooperatif Tipe NHT dalam Upaya Meningkatkan Hasil Belajar Matematika Siswa di SMP Negeri 1 Sukarame Kabupaten Tasikmalaya Jawa Barat. Jurnal Saung Guru, Volume 02 (02), 9 halaman.

Wahyuni, M., Rahayu, W., \& Widyati, R. (2017). Perbandingan Kemampuan Berpikir Kritis Matematis Antara Siswa Yang Belajar Menggunakan Model Problem Based Learning Dan Model Reciprocal Teaching. Jurnal Riset Pembelajaran Matematika Sekolah, 1(1), 37-45.

Yansen, I K.E. 2014. Penerapan Model Pembelajaran Kooperatif Tipe NHT untuk Meningkatkan Hasil Belajar Siswa pada Materi Pertidaksamaan Linear Satu Variabel di Kelas VII SMPN 9 Palu. Jurnal Elektronik Pendidikan Matematika Tadulako. 01, (02), $156-167$. 